\title{
Disaster Resilient Village Based on Sociocultural Aspect in Ponorogo
}

\author{
${ }^{1}$ MUHAMAD FAJAR PRAMONO, ${ }^{2}$ SETIAWAN BIN LAHURI, ${ }^{3}$ MOHAMMAD GHOZALI \\ 1,2,3 Universitas Darussalam Gontor, Jl. Raya Siman Km. 5, Siman, Ponorogo, Indonesia \\ correspondence author: mfpramono@unida.gontor.ac.id;
}

\begin{abstract}
Real landslides management in Indonesia is formulated in the form of a resilient village (Destana/Desa Tangguh Bencana). In Ponorogo, there is one village as a role model of Destana that is Tugurejo village. The purpose of this study is to explore the beneficial advantages of implementing the Destana program in Tugurejo. The other 11 disaster-resilient villages in Ponorogo area will also be explored in other programs. The method used in this study is grounded research. The results of the study show that Tugurejo village has a good management institution and the spirit of mutual cooperation. Furthermore, the village head's leadership that firmly maintains the local wisdom as a form of collaboration of social and cultural aspects was forcing the village development, at least in the case of Tugurejo Village, and built the ability to perform synergy with stakeholders.
\end{abstract}

Keywords: disaster, socio-cultural, tugurejo

\section{Introduction}

The study of disasters can be carried out by various scientific disciplines, including geography, anthropology, engineering, health, development studies, and sociology (Peter L. Berger, 1963). The sociological approach discusses the vulnerability and impact of disasters on human behavior patterns and their effects on the functioning of community structures and organizations. In a sociological perspective (Thomas E. Drabek, 2013), disaster is often understood based on human or community perceptions, and about how they feel is related to emotional experiences in events that can threaten their survival. Disaster is one of the definitions compiled in a socio-cultural context of community life that has experienced a disaster (R. Pramono, 2016).

The study of disasters in the last decade shows that there has been a change in orientation, which initially discussed more about technical issues about events that triggered disasters and the handling of disaster victims into approaches that emphasize human and community approaches (Thomas
E. Drabek, 1986). This led to the proposal of disaster management in integrated community development. It also states that disaster management should not be overcome with a physical approach that is only for a moment, but should also carry out sustainably in accordance with the socio-economic life of local people who are vulnerable and affected by disasters; Akmal called it a sociological disaster (Saputra, 2016).

Each community has the knowledge and ways to deal with the environment to survive. This knowledge and method are known as "wisdom to cope with the local events" or often being shortened to "local wisdom" (Ruslanjari, 2010). The facts show that the community develops knowledge to understand how nature works and then follows it, and also tries to avoid things that can threaten safety. Knowledge of how to build houses and households; knowledge of farming or cultivation traditions with rules for selecting the location of field (huma), the right time to cultivate, procedures for opening and burning land, and avoiding the danger of landslides and fires, are examples of how the

Received: 2020-03-28, Revised: 2020-05-05, Accepted: 2020-06-03 
community develops knowledge to survive and develop life (Hariadi et al., 2020).

The description above explains that local wisdom is a local knowledge system that is stored in the community's memory and will start working immediately when the conditions that require it to work have come. Furthermore, a coping mechanism is formed and born from experience, knowledge, understanding, and the meaning of every event, phenomenon, hope, and problems that occur around the community. The mechanism is continued through the process of socialization from generation to generation and its implementation depends on the level of quality of understanding and its implications in their lives (Maarif et al., 2012).

Nowadays, the role of local wisdom or also referred to as local knowledge in disaster risk management and reduction is becoming a rapidly developing discussion (Jessica Mercer et al., 2010). Defines local knowledge as a set of existing and believed knowledge of local communities within a certain period through the accumulation of experience, community relations with nature, practices, and community institutions that passing down between generations (Maarif et al., 2012). All knowledge is dynamic, constantly changing, developing, and adapting due to people's responses to changes in their environment. Over the years, local people have responded to their environment and adapted to change using both modern science and local knowledge (Agrawal, 1995). The interaction between modern knowledge and local knowledge is not new. Modern knowledge and local knowledge are often involved in power relations (J Mercer et al., 2009). Each community has a diverse epistemology in viewing and interpreting natural disasters that occur (Maskud, 2016).

The mandate of Law Number 24 Year 2007 concerning disaster management is to protect the public from the threat of disaster. One strategy to achieve this is through the development of villages that are resilient to disasters with efforts to reduce community-based disaster risk (PRBBK). In PRBBK, the process of disaster risk management actively involves the community in assessing, analyzing, handling, monitoring, and evaluating disaster risk to reduce vulnerability and enhance its capabilities (UU No. 24 Tahun 2007 tentang Penanggulangan Bencana, 2007).

Disaster Resilient Village is a village that can recognize threats in its area and can organize community resources to reduce vulnerability while increasing community capacity and capability to reduce the risk of disaster. This capability is manifested in development planning which includes prevention, alertness, disaster risk reduction, and capacity building for post-disaster recovery. In Destana, communities are actively involved in assessing, analyzing, handling, monitoring, evaluating, and reducing the risk of disasters in their area, especially by utilizing local resources to ensure sustainability (Kepala BNPB, 2012).

The National Disaster Management Agency (BNPB) has implemented PRBBK by developing the Resilient Village (Destana) program. The Destana Program from 2012 to 2015 had already reached 266 villages/ subdistricts throughout Indonesia. In 2016, the plan was BNPB would re-develop 100 villages to become Destana. The reference used in implementing the Destana program is the Regulation of the Head of the National Disaster Management Agency No. 1 of 2012 concerning General Guidelines for Resilient Villages (Kepala BNPB, 2012). This regulation was established by the Head of BNPB, Syamsul Maarif, on January 10, 2012, in Jakarta. The objectives of Perka BNPB No. 1/2012 is to: 1) Provide guidance for the government and/ or local government in developing Destana as part of the PRBBK effort. 2) Provide a reference for the implementation of the development of Destana for the implementing apparatus and stakeholders in disaster risk reduction (DRR).

In Ponorogo region, there is one of the Destana that has already become a model, namely Desa Tangguh Bencana (Destana) Tugurejo, Slahung, Ponorogo. According to the Head of the Regional Disaster Management Agency (BPBD), Drs. Imam Bashori, M.Si (Imam Bashori, 2019) there are 11 villages designated as disaster villages (Destana) in Ponorogo and are divided into three clusters, namely: first, the Disaster Resilient Village (Destana) in the Main category, consisting of 1) Tugurejo Village, Slahung District; 2) Dayakan Village, Badegan District; 3) Maguan Village, Sambit District and 4) Banaran Village, Slahung District. Second, Destana in the Middle category, consisting of 5) Jurug Village, Sooko District and 6) Senepo Village, Slahung District. Third, Destana in Primary category, consisting of 7) Sooko Village, Sooko District; 8) Tumpuk Village; 9) Tempuran Village, Sawoo District; 
10) Bekiring Village, Pulung District, and 11) Slahung Village, Slahung District.

According to the Head of the BPBD Prevention Section in Ponorogo Regency, Marem, S. Sos., M.Sc. (Marem, 2019), referring to PERKA BNPB No. 1/2012, the Destana program was developed based on the following principles: (1) Disasters are joint affairs, (2) Disaster Risk Reduction Based (PRB), (3) Fulfillment of community rights, (4) Communities are the main actors, (5) Conducted participatory, (6) Mobilization of local resources, (7) Inclusive, (8) Based on humanity, (9) Justice and gender equality, (10) Siding with groups, (11) Transparency and accountability, (12) Partnerships (13) Multi threats, (14) Autonomy and decentralization of government, (15) Integration into sustainable development, and (16) Organizing across sectors. The components of Destana include (1) Legislation, (2) Planning, (3) Institutional, (4) Funding, (5) Capacity building, and (6) Organization of PB (Disaster Reduction).

Still according to the Head of Prevention of BPBD of Ponorogo Regency, Marem, S. Sos., M.Sc. (2019), by referring to Perka BNPB No.1/2012, strategies for realizing Destana include (1) the Involvement of all layers of the community, especially those who are most physically, economically, environmentally, and socially vulnerable, in line with the needs of mainstreaming gender programs; (2) Special pressure on the use and utilization of local resources with minimal external facilitation; (3) The development program of synergy with all actors (ministries/ institutions, social organizations, business institutions, and universities) to empower rural/urban communities; (4) Support in the form of commitment to policies, assistance, and technical assistance from central, provincial, district/city governments, if necessary; (5) Improve knowledge and awareness of the potential threats to their village/urban village and will require citizens' efforts; (6) Reduction in rural/ urban community disaster risk; (7) Increase community capacity to reduce and adapt to disaster risk; (8) The overall implementation of the risk management series consists of risk identification, risk assessment, risk conflict, mitigation, risk recovery, and risk transfer; (9) Integrating DRR efforts with the development for the sustainability of the program; (10) Mainstreaming DRR into planning programs and social/village/village institutional/institutional activities so that DRR can cover all activities at the community level.

The purpose of this study is to explore the beneficial advantages of implementing Desa Tangguh Bencana (Destana) program in Tugurejo. Other disaster-resilient villages (9 villages) in Ponorogo area will also be explored in the next program. The disaster-resilient village (Desa Tangguh Bencana, Destana) of Tugurejo, Slahung, was chosen as the main object of the study by taking into account the principles mentioned above and also based on the availability and competence of human resources and institutions, as well as its programs before and after it was determined as the Main Resilient Village (Destana Utama) by the government (central and regional) which continuously sustainable. Furthermore, various advantages and disadvantages from other villages will also be explored, such as in Dayakan Village, Badegan, Jurug Village, Sooko, and seven other villages.

The benefit of this research is the making of a blueprint of disaster management in Ponorogo based on social culture so that it can become an evaluation and guide for the management of landslides in Ponorogo, both conducted by the Regional Disaster Management Agency (BPBD) of Ponorogo Regency and the community vulnerable to landslides in the form of academic studies as a pre-requisite for the birth of a Regional Regulation (Perda).

\section{Research Methodology}

The method applied in this study is grounded research (Rennie, 1998), which is a study that uses comparative analysis with the aim of carrying out empirical generalizations, establishing concepts, proving theories, and proposing new theories.

This research was conducted for two years. The first year of this research aimed at (1) Compiling a blueprint of landslide disaster management in Ponorogo Regency from the Sociological Aspect; (2) Exploring management models as outlined in both of the results of studies or in the rules of Ponorogo Regency and other Regencies. 3) Arranging an appropriate formulation in the framework of the compilation of a blueprint for the management of landslides in Ponorogo Regency from the Sociological Aspect.

Relevant research results used in this study are: (1) Penerapan Manajemen Krisis dalam Pengelolaan Bencana Longsor 
Banaran, Pulung, Ponorogo (Muhamad Fajar Pramono, dkk, 2017); (2) Penerapan Manajemen Krisis di Indonesia: Memotret Krisis Dalam Kacamata Public Relations (Marsefo S. Luhukay, 2008); and (3) Kesiapsiagaan Masyarakat Terhadap Kerawanan Tanah Longsor di DAS Bompon Kabupaten Magelang Sadewa (Permana, 2016). From the results of those studies aforementioned, the researcher obtained data of the arrangement of problems, objectives and outcomes, and relevant theories for this study.

Baseline Survey. The next thing to do is mapping the following: (1) Human resource readiness at district, sub district, and village levels that are determined as Destana; (2) inventory of Landslide management models and specifications of each of these models; (3) Explore partnerships with both government and private.

Models. In this research, we try to focus on the implementation model of Destana in Ponorogo in general, such as Dayakan Village, Badegan District; Maguan Village, Sambit District; Banaran Village, Slahung District; Jurug Village, Sooko District, and Senepo Village, Slahung District; Sooko Village, Sooko District; Tumpuk Village and Tempuran Village District of Sawoo; Bekiring Village, Pulung District and Slahung Village, Slahung District. An in-depth examination of Destana implementation is specifically carried out in Tugurejo Disaster Village, Slahung District.

Primary Data Collection. Some activities in order to strengthen the theory and mapping are (1) Focus Group Discussions with experts from Gadjah Mada University related to landslides and sociologists from Airlangga University related to socio cultural perspectives; (2) Conducting site visits, especially to the villages determined as disaster-resilient villages by the Ponorogo government, specifically Tugurejo village, Slahung sub-district; (3) Conducting Public Consultation, especially with BPBD, Social Service, Polres (regency police), Kodim (military districts), and other stakeholders.

Data Analysis. The result of the literature review, expert discussion, and model mapping is then processed by using (1) Sociological foundation; (2) Theoretical \& Empirical.

Studies in the framework of a compilation of blueprint draft for landslide disaster management in Ponorogo viewed from the Sociological Aspect.

The method procedure was technically and simply explained in figure 1 .

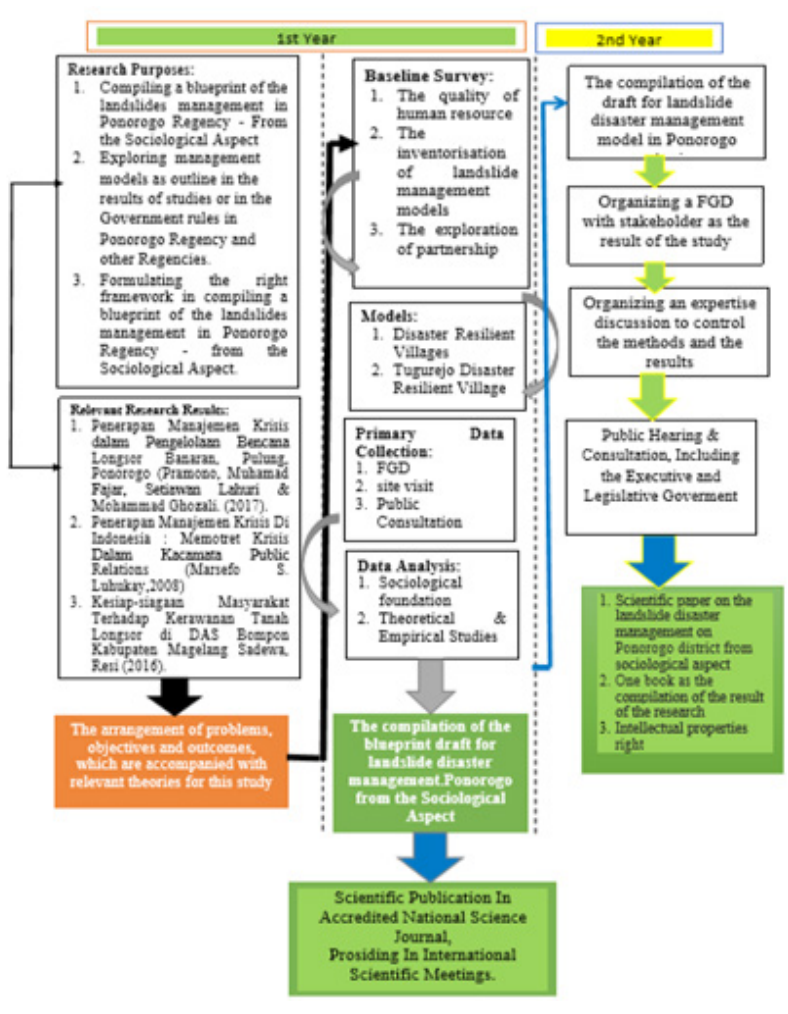

Figure 1

Systematic Research

\section{Results and Discussion Results}

The results of this study will illustrate the level of vulnerability to landslides in Ponorogo in the context of East Java, Desa Tangguh Bencana (disaster resilient village) in Ponorogo, Desa Tangguh Bencana Tugurejo as a model.

\section{Ponorogo and Landslides Disaster}

Based on data from the East Java Regional Disaster Management Agency (BPBD), out of 38 regencies/cities, 20 regions are categorized as prone to landslides in high, medium, and light categories. The 20 areas are Pacitan, Blitar Regency, Trenggalek, Ponorogo, Batu, Lumajang, Jombang, Malang Regency, Probolinggo Regency, Jember, Bojonegoro, Madiun Regency, Mojokerto Regency, Pasuruan Regency, Nganjuk, Situbondo, Bondowoso, Tulungagung, Magetan, and Kediri. Probolinggo Regency is one of the areas included in the highland category of landslides.

Whereas, based on historical incidents in DIBI data (BPBD, 2019), the Bogor 
Regency in 2008-2017 underwent 85 landslide disasters which caused suffering and losses of objects. The area under landslide threat in Bogor Regency is an area with a high level of deforestation, deforested lands in protected forest areas, rainfall and high altitude, and a region with a slope of more than $40 \%$. More land movements in the District of Monograms occur in areas with the utilization of similar forest types and dense forests.

Land movements in Ponorogo Regency are more common in areas with the utilization of similar forest and dense forests. Rainwater condition is an important factor that can trigger soil movement, especially rainfall. Some surface water that comes from rainfall will seep into the soil/rocks through soil pores or cracks and some will flow above the soil surface. As soil mass weights increase, the shear strength of the soil will decrease. That kind of situation, if supported by other factors such as a steep slope and/or the inappropriate land use, will trigger soil movement.

\section{Table 1}

\section{Natural Disasters in Ponorogo Regency and their Impacts (2008-2017 Period)}

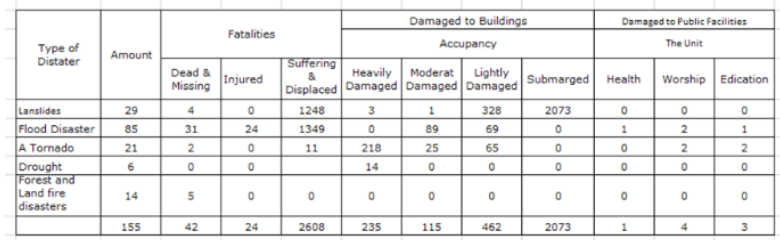

Source: Dokumen Kajian Risiko Bencana Kabupaten Ponorogo 2019-2023

Literature Study of Disaster Risk of Ponorogo Regency 2019-2023

Based on table 1, there are 5 types of disasters that have occurred in Ponorogo Regency with a total of 155 events (BPBD, 2019). First, a landslide is the most frequently occurring disaster with a total of 85 incidents, causing 31 people died/disappeared, 24 people were injured, 1349 people were displaced, 218 houses were severely damaged, 89 houses were moderately damaged, and 69 houses were slightly damaged. It also damaged 1 health facility, 2 worship facilities, and 1 education facility. Second is flood disaster (29 events) as the most common type of disaster after a landslide. Flood disaster caused 4 people died/disappeared, and 1248 people were displaced. Flood also damaged 3 houses, 1 was damaged moderately, 328 houses were slightly damaged, and 2073 houses were submerged. Third is tornado (21 incidents) caused 2 people died/disappeared and 11 people were displaced. The tornado also caused 14 houses had heavily damaged conditions, 25 moderately damaged, 65 lightly damaged. It damaged 2 worship facilities and 2 education facilities. Fourth is a drought that has happened 6 times in Ponorogo Regency which caused fewer casualties and other damage. Fifth is forest and land fire disasters occurred 14 times causing 5 people to die/ disappeared.

\section{Disaster Resilient Villages (destana) in Ponorogo}

Interestingly, all the disaster-resilient villages (Destana) determined by the government, either included in the main category, middle category, and primary category in Ponorogo Regency are located on the slope of the mountain. These factors which then lead to landslides often occur year after year, and it is even getting worse (Iman Sulardi, 2019) especially in the rainy season (Tri Wahyono, 2019). In addition, the community is aware of the landslide, so that they know what to do. For example, each citizen is responsible for their environment, which commonly known as mutual cooperation (Sarnu, 2019), including being able to conduct early detection using simple equipment such as sticks tied with threads to detect ground movements (Siswanto, Tugurejo, 2019).

According to Dina Ruslajari, such attitudes or behaviors are called local wisdom, which is the value created, developed, and maintained in the community due to its ability to survive and become a guide for people's lives. Local wisdom includes various mechanisms and ways to behave and act as outlined in the social order. Based on Lee and Tesoriero, 2002 (Ruslanjari, 2010), there are six dimensions of local wisdom, namely local knowledge, local culture, local skills, local resources, local decision-making mechanisms, and group solidarity. These six dimensions are local intelligence that is transformed into creativity, work, and initiative so that the community can be independent in facing various changes in the social climate.

In addition to the Tugurejo Destana village discussed by the researcher, there are 3 other Destana villages, namely Banaran Village in Pulung District, Jurug Village in Sooko District, and Dayakan Village in Badegan District which will also be briefly reviewed in this paper. The first village is Destana Banaran in Pulung District, about 33 
$\mathrm{km}$ east of Ponorogo city which also becomes a national concern. Due to the heavy rain, the village was hit by a landslide (2017) that destroyed residents' homes. Based on data collected, the landslide center occurred at RT 01 RW 01 Dukuh Tangkil, Banaran Village, Pulung District, Ponorogo Regency, East Java (Sarnu, Banaran, 2019).

Landslides buried many residents' homes. It was not just that, many people also suffered injuries because of the landslides. They were injured due to crushed rubble of houses, fallen trees, and rocks. At least 23 residents' houses were buried and destroyed. Instantly, Ponorogo immediately became an interesting icon for national mass media coverage. This is due to the absence of records of landslides that had an impact of this magnitude before. The landslide in Banaran Village caused more than 20 deaths (M. F. Pramono et al., 2018). An important note from the Head of Banaran Village, Sarnu, is that to change the mindset of people to not rely on chemical drugs in farming and the necessary to arrange the drainage system (Sarnu, Banaran, 2019).

In Jurug Village, Sooko District, there was also a landslide but not as large as in Banaran, Pulung District. As a result, two houses in Jurug and Bedoho villages in Sooko sub-district became victims of landslide attacks. The data collected from the Regional Disaster Management Agency (BPBD) of Ponorogo Regency reveals that the landslide hit the house owned by Soirin (60), a resident of RT. 02, RW. 01 Srayu Hamlet, Jurug Village, Sooko District, Ponorogo Regency; and Sarwi (53), a resident of RT 03 RW. 04 Sepung Hamlet, Bedoho Village, Sooko District. There were no casualties in this incident but the loss was estimated to reach tens of millions of rupiah, given the damage to some of the houses as an impact of a landslide. Jurug Village is one of the resorts that participated in the competition of Destana in East Java, mainly because of the readiness of human resources and well-managed institutions (Sukamto, Jurug, 2019).

During the arrangement, the first thing to note is related to the budget. It could be taken from the Village Fund Allocation (ADD), but it was not. This was caused by one of the clauses that are stated before. Media reporting is often being too dramatic causing officials to be in uncomfortable positions, both at the sub-district and district levels. Media reporting raises the perception as if there is no solution and any action from the Government. Even from the positive side, assistance and sympathy from the outside are quite good.

Dayakan Village in Badegan District, located about $22 \mathrm{~km}$ of west Ponorogo City, East Java, was suffering from a land crack in 2017. The land crack occurred in the hills of 1 -meter width, 300 meters depth, and 300 meters in height. The land cracks affected 56 households consisted of 285 people and they need to be evacuated. Dayakan resort has never been submitted in Destana competition, but it has a reforestation program as a part of disaster management, emergency, and policy programs funded by the Village Fund Allocation (ADD) of 20 million Rupiah which is presented in figure 2 . An effort to prevent landslides will create a tourist village that combines forests, mountains, and fisheries. The village is still in the exploratory stage and trying to learn from other tourist villages such as Ngrambang, Sine District, and Ngawi Regency (Saroni, 2019).

\begin{tabular}{|c|c|}
\hline PENDAPATAN $\quad:$ Rp 2.560.066.961,- & \\
\hline $\begin{array}{l}\text { Pendapatan Asli Desa } \\
\text { Dana Desa } \\
\text { Alokasi Dana Desa } \\
\text { Bagi Hasil Pajak dan Retribusi } \\
\text { Bantuan Keuangan Provinsi } \\
\text { Bantuan Keuangan dari APBD Kabupaten } \\
\end{array}$ & $\begin{array}{lr}R p & 131.400 .000 \\
R p & 1.376 .267 .000 \\
R p & 541.802 .000 \\
R p & 28.197 .961 \\
R p & 50.000 .000 \\
R p & 432.400 .000 \\
\end{array}$ \\
\hline $\begin{array}{ll}\text { BELANJA } & : \text { Rp 2.465.289.731,0 } \\
\end{array}$ & \\
\hline $\begin{array}{l}\text { Bidang Penyelenggaraan Pemerintah Desa } \\
\text { Bidang Pelaksanaan Pembangunan } \\
\text { Bidang Pembinaan Kemasyarakatan } \\
\text { Bidang Pemberdayaan Masyarakat } \\
\text { Bidang Penanggulangan Bencana, Darurat } \\
\text { dan Mendesak Desa } \\
\end{array}$ & $\begin{array}{lr}\text { Rp } & 736.218 .766 \\
\text { Rp } & 1.502 .461 .400 \\
\text { Rp } & 111.230 .965 \\
\text { Rp } & 95.378 .600 \\
& \\
\text { Rp } & 20.000 .000 \\
\end{array}$ \\
\hline Surplus / Delisit : Rp 94.777.229,96 & \\
\hline PEMBBIAYAAN & \\
\hline $\begin{array}{l}\text { Penerimaan Pembiayaan } \\
\text { Pengeluaran Pembiayaan } \\
\text { Pembiayaan Netto } \\
\text { SILPA }\end{array}$ & $\begin{array}{rr}\text { Rp } & 5.222 .770 \\
\mathrm{Rp}_{p} & 100.000 .000 \\
\mathrm{Rp} & (94.777 .230) \\
\mathrm{Rp} & 0 \\
\end{array}$ \\
\hline
\end{tabular}

Figure 2 APBDes (Village Budget)

Source: Dayakan District Budget Year of 2019

Banaran Village in Pulung District, Jurug Village in Sooko District, and Dayakan Village in Slahung District have something called local wisdom. Although it is very simple it can be developed optimally. In contrast to programs originating from the government, although supported by substantial funds and various parties, the results are not optimal, especially in terms of responsibilities. They assume that programs that do not emerge from community initiatives are projects and only waste the budget, for example, in the case of Sooko Village. The results will be different if the program is produced from village consultation meetings/RT meetings, then the community 
would have a sense of responsibility (Sudarto, Sooko, 2019).

\section{Disaster Resilient Village, Tugurejo, Kecamatan Slahung}

In 2016, in Destana Tugurejo, Slahung District, Ponorogo, 39 houses were cracked and sinking. It was caused by ground movement in the area. After repeatedly experiencing land/earth cracks, Ureure village was then hit by a landslide, precisely at Krajan Hamlet, Tugurejo Village, Slahung District, Ponorogo Regency. The landslide occurred due to heavy rain the day before with moderate water intensity (Siswanto, Tugurejo, 2019).

In disaster management, the efforts, rapid, appropriate and integrated alertness, and coordinated alertness through a program of activities and prevention in the Tugurejo village, Slahung Sub-district, has a vision of "Tetap Jaya Berbudaya dan Religius" (victorious, cultural, religious) as outlined in Village Regulation (Perdes) number 07 of 2017. The purpose of regulation as it states in (Article 4): (a) building a systematic, planned, structured, integrated, dynamic and sustainable disaster management system; (b) provide protection for the community from the threat of disaster; (c) Encourage participatory enthusiasm, mutual cooperation, and solidarity; (d) Build participation and political partnerships and private world; (e) Respect local culture and wisdom.

In the context of village disaster management activities, the sources of funds are (a) Village budget and urban village budget; (b) Financial assistance from the Regency APBD, Provincial APBD, and the Central APB, which is presented in figure 3. Legitimate and non-binding third party assistance (Article 8 ).

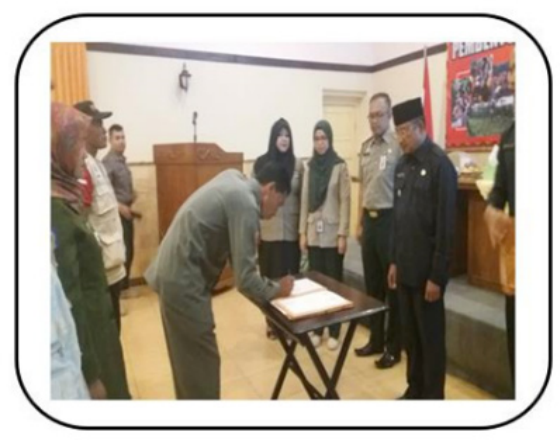

Figure 3 Signing of $\mathrm{MoU}$

Source: Tugurejo District, 2019 In disaster management efforts, rapid, appropriate and integrated alertness, and coordinated preparedness through the Head of Tugurejo Village's program number 47, Slahung sub-district requires the involvement of younger generation/KarangTaruna by forming the Disaster ResilientYouth Organization (TAGANA) through the Decree of the Head of Tugurejo Village number 47 in 2017, led by Muhammad Syarifuddin. Meanwhile, the tasks of TAGANA are strengthened by SK (decree) number 01, 2018 concerning the establishment of cooperation in maintaining forest security in the area of the Wonodadi Forest Village Community Institution (LMDH) with the Tugurejo Village Youth Organization (TAGANA), which are: a. Together in activities to preserve the Perhutani forest and its surroundings. b. Together in preventing the danger of forest fires in Perhutani and surrounding areas. c. Together in the context of early prevention of landslides in the forest area of Perhutani and its surroundings.

Disaster management efforts require immediate, integrated, and coordinated preparedness involving women to form a Village Disaster Resilient Woman (PERTAHANA) through the Decree of the Head of Tugurejo Village number 07 Year 2018 led by Kartini. Other than that, in order to strengthen disaster management efforts, rapid, appropriate and integrated preparedness, it is necessary to form a Disaster Risk Reduction Forum (PRB) through the Decree of the Head of Tugurejo Village number 32 of 2018 with the tasks of preventing the emergence of disasters; reducing disaster risk holistically and integrated before, during and after disasters; coordinating and managing the receipt and distribution of assistance; carry out recovery through cross sectoral programs, and continuously report the results of tasks implementation to the Regent of Slahung District. To prevent confusion and overlap related to duties and authority, organization and work procedures of the management of Tugurejo Village is regulated through the decision of the Head of Tugurejo Village number 33 in 2018.

The superiority of disaster-resilient village (Destana) of Tugurejo, aside from being institutional, is the dynamic condition of the community under the leadership of Siswanto as the Head of Village. This can be seen in the involvement of Tugurejo village in various competitions both at Kabupaten Ponorogo level and East Java Province levels, such as 1st Champion of the Best Team of Mutual Cooperation Implementation in Ponorogo 
Regency 2019 which has the right to represent the Ponorogo Regency to East Java Province and also in the TP-PKKE competition and Village Economic Development Assessment 2019 of East Java Province. Relating to Destana, this village also won 1st place in PERTAHANA, the Disaster Resilient Woman, and the Village Innovation Exchange (BID) of Ponorogo Regency. Currently, it represents Ponorogo in the Desa Tangguh Bencana (disaster-resilient) competition at the East Java level (2019).

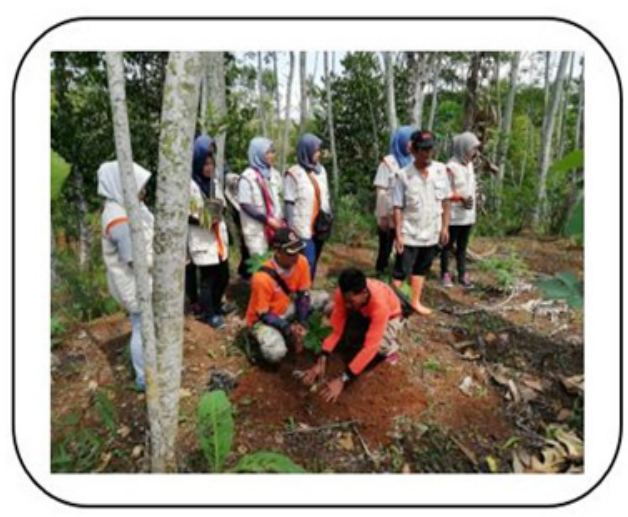

Figure 4

Agro-Forestry to Reduce the Risk of Disaster in Critical Area

The disaster risk reduction program (PRB) in Tugurejo Village (throughout 20172018) was quite dynamic and productive. The programs, among others, are the reforestation program of disaster-prone areas along with tagana pertahana and vespa communities, agroforestry to reduce the risk of disasters on critical land presented in figure 4 , the development of land conservation through the community forest program, the development of community forests, land conservation applying a terracing system, the provision of green seedlings, coffee seedlings as plantation business, and early prevention of disasters.

Another factor that cannot be ignored from the superiority of DestanaTugurejo, Slahung District is the leadership of Siswanto as the head of the Village. The vision of his leadership is "Tetap Jaya Berbudaya dan Religius", having a sense of responsibility, creativity, innovation, and independence. The interesting statement came from Siswanto during appreciating Tugurejo achievement that won 1st place in the 2019 Ponorogo Regency Mutual Cooperation Competition and represent Ponorogo Regency for the competition to the Provincial Level of East Java, saying that the success and achievement could not be separated from the seriousness and great enthusiasm of all elements in the community and village apparatus. All forces work in synergy to achieve the mutually agreed targets. The spirit of never giving up and Tanggon (reliable) Tangguh (strong) and Tutug (committed) together with the support and prayers from the entire community of Tugurejo Village with the motto "Guyub rukun mbangun deso tumuju rahayuning bumi Tugurejo" (building the welfare of Tugurejo village together) to get the best (Siswanto, 2019). This is the spirit that is always stirred the movement of Tugurejo Disaster

\section{Resilient Village Discussion}

Based on the description above, the effectiveness of Destana is highly determined by several factors: natural conditions, human resources (HR), conceptual and readiness program, and socio-cultural.

\section{Natural Conditions}

According to Danang Sri Hatmoko (Hadmoko \& Mauro, 2015), there is no simple and ideal classification system for landslides due to its high level of complexity. However, slope damage can be classified into a mechanism, type of material, slip surface morphology, and speed of Rockfall movement, Topples, Sliding, Lateral spread, and Debris flow. In general, almost all Destana is located in Mountain Cliffs, where almost every year experience landslides, both large and small scale.

In a sociological perspective, natural phenomena in the form of landslides are not new since it happens from year to year, especially in the rainy season. The community is getting used to facing such conditions. They know what to do and do not from their elders. Each community group has the knowledge and ways to deal with the environment for its survival. This knowledge and method are known as "wisdom to cope with the local events" or often shortened into the term "local wisdom". For example, in the Simeuleue community, there is local wisdom called Smong that is knowledge passed down from generation to generation on how to act when they face tsunami disaster. Attitude is a perception and behavior consisting of cognitive, affective, and conative components. This attitude is what underlies a 
person to react to the stimulation of an object (Juhadi, Wahyu Setyaningsih, 2016).

Likewise, in the context of landslides, the community has been conditioned to face the situation, both in early anticipation or when facing the landslide. And actually, the community is aware of the landslide and they know what to do. Each citizen is responsible for the environment, which is commonly known as mutual cooperation (Sarnu, Banaran, 2019), and being able to do early detection using simple equipment such as a stick tied with a thread to detect soil movement (Siswanto, Tugurejo, 2019).

\section{Human Resources}

It also states that human resources are one of the resources contained in the organization, including all people who carry out human resource activities and are a dominant factor that must be maintained in the implementation of development in order to facilitate the achievement of national development goals. The quality of the human resource is not seen merely from education but from their ability to be independent (Notoatmojo, 2010).

Many villagers living in the mountain feel a dilemma. One factor is due to economic conditions, such as those in Jurug Village in Sooko District, Bekiring Village and Banaran Village in Pulung District, and Dayakan Village in Badegan District. Many of them go out to work and even abroad as migrant workers. Regarding that, the Head of Tugurejo Village has a responsibility to provide jobs and forms the organization of the Disaster Resilient Youth Organization (TAGANA) through the Decree of the Village Head of Tugurejo number 47 in 2017.

There is also certainty about the position and roles carried out in the context of Destana among young women, especially in optimizing the role of youth/young women who are still in school, as well as to enrich their experience for future capital. By referring to Perka (the head of division regulation) BNPB No. 1/2012 stating that the Destana program is developed not solely based on the principle that disasters are a common affair, but it is also important for the community to be the main actors who mobilize local resources which integrated into sustainable development. It means that human resources in an organization with a strategic role in improving the quality of performance in achieving organizational goals, as well as in the context of Destana.

\section{Concept and Program}

It is interesting to note that the disaster risk reduction program (PRB) in Tugurejo Village (throughout 2017-2018) is quite dynamic and productive, including routine greening programs in disaster-prone areas along with tagana pertahana and vespa communities, agroforestry to reduce the risk of disasters on land critical, the development of land conservation through the community forest program, the development of community forests, the conservation of land using terracing system, the provision of reforestation seedlings, the seedbed of coffee seeds as a plantation business, as well as early prevention of disasters.

Thus, several concepts and programs have developed in the community, such as cooperation (Banaran and Tugurejo), village consultation (Sooko), changing mindsets about chemical drugs (Banaran), and synergy with forest communities (Tugurejo). However, in general, it is sporadic and less measurable. Maybe it can be developed optimally because it's very simple and precise.

On the other hand, the government programs, although it is supported by relatively large funds with support from various parties, the results of the program are not optimal, especially in terms of responsibility. They think that a program that is not from a community initiative is understood as a project that wastes the budget, for example, in the case of Sooko village. It would be different if the program is coming out from village consultation meetings/RT meeting, in which the community has a greater sense of responsibility for (Sudarto, Sooko, 2019).

\section{Socio Cultural}

Landslides know no social and cultural status. All communities show their social solidarity, either the Javanese religious group and the santri group. Both the kejawen group and santri group have a social concern for disaster risk reduction. Uniquely, each group has its strategy in reducing disaster risk, either in pre disaster, during emergency response, and post-disaster. Sometimes, the practice of disaster risk reduction (DRR) is carrying out by integrating the understanding of Javanese community and santri community through performing certain rituals. 
Every phenomenon of natural disasters can be known through the structure of human understanding and experience in the disaster area. Since a long time ago, the local communities in Indonesia have had a profound knowledge of the symptoms associated with natural disasters that will happen. This knowledge, which is inherited from generation to generation, also developed throughout the experience dealing with natural disasters. Thus, people who have experienced a disaster in a long time will have a self-defense mechanism in response to any disasters. The exception is those people who are recently suffered from natural disasters; they get shocked and panic. These people do not have adequate mechanisms to respond to disasters. Argues that a disaster is considered as a new experience, something unprecedented so that it is taken as collective knowledge and experience (Alwi et al., 2017).

\section{Conclusions}

Natural disasters are unavoidable phenomena, including landslides. Each community group has the knowledge and ways to deal with the environment to survive. Knowledge and method are known as "wisdom to cope with the local events". The mechanism in dealing with events (coping mechanisms) is formed and born from experience, knowledge, understanding, and the meaning of each event, phenomenon, hopes, and problems that occur. The mechanism is continued through the process of socialization from generation to generation and its implementation depends on the level of quality of understanding and its implications on the lives of the village. Destana is a village that has the ability to recognize threats in its area and be able to organize community resources to reduce vulnerability and at the same time, increase capacity to reduce disaster risk. The advantage of Tugurejo Disaster Resilient Village in addition to the readiness of institutional and program aspects is the spirit of mutual cooperation that still exists in the Tugurejo community. Moreover, the village head's leadership firmly maintains the existence of what is called "local wisdom", that is a form of collaboration of social and cultural aspects as a force of development and the ability to build synergy with stakeholders.

\section{Acknowledgment}

This research was carried out in collaboration with UNIDA Gontor and KemenristekDikti Fiscal Year 2019. The authors would like to thank both institutions for the support of various facilities for the implementation of this research and the composition of this paper. Hopefully, it will benefit the progress of the Indonesian people.

\section{References}

Agrawal, A. (1995). Dismantling the Divide Between Indigenous and Scientific Knowledge. Development and Change. https://doi. org/10.1111/j.1467-7660.1995. tb00560.x

Alwi, I., Mustansyir, R., \& Hadi, P. H. (2017). Natural Disasters Management in Indonesia: Perspective of Local Wisdom and Heidegger Hermeneutics. Al-Albab, 6(1), 77. https://doi.org/10.24260/ alalbab.v6i1.730

BPBD. (2019). Dokumen Kajian Risiko Bencana Kabupaten Ponorogo 2019-2023.

Hadmoko, D. S., \& Mauro, S. E.-D. (2015). Landslide and other Mass Movements. In Handbook of Hazards and Disaster Risk Reduction. https://doi. org/10.4324/9780203844236.ch25

Hariadi, U., Suratman, S., Gunawan, T., \& Armawi, A. (2020). Kearifan Lokal Komunitas Sebagai Modal Sosial alam Manajemen Bencana Alam. Majalah Geografi Indonesia, 33. https://doi. org/10.22146/mgi.48548

Imam Bashori, H. of B. P. (2019). Interview. Iman Sulardi, T. D. (2019). Interview.

Juhadi, Wahyu Setyaningsih, N. K. (2016). Pola Perilaku Masyarakat Dalam Pengurangan Resiko Bencana Tanah Longsor Di Kecamatan Banjarwangu Kabupaten Banjarnegara Jawa Tengah. Jurnal Geografi, 13(2), 216-224. https:// doi.org/10.15294/jg.v13i2.7978

Kepala BNPB. (2012). Peraturan BNPB NO 1 2012. Peraturan BNPB NO 12012.

Maarif, S., Pramono, R., Kinseng, R. A., \& Sunarti, E. (2012). Kontestasi Pengetahuan dan Pemaknaan Tentang Ancaman Bencana Alam (Studi Kasus Ancaman Bencana Gunung Merapi). Jurnal Penanggulangan Bencana.

Marem, H. of the P. B. P. S. (2019). Interview. Maskud. (2016). Kearifan Lokal dalam Penanggulangan Bencana Banjir Bandang dan Tanah Longsor di Kecamatan Panti Kabupaten Jember. Jurnal Fenomena: IAIN Jember. Diakses Pada Hari Selasa 
30 Juli 2019. Pukul 00:53 WIB.

Mercer, J, Kelman, I., Taranis, L., \& SuchetPearson, S. (2009). Integrating indigenous and scientific knowledge bases for disaster risk reduction in Papua New Guinea, Geografiska Annaler: Series B. Human Geography. https://doi.org/10.1111/ j.03613666.2009.01126.x

Mercer, Jessica, Kelman, I., Taranis, L., \& Suchet-Pearson, S. (2010). Framework for integrating indigenous and scientific knowledge for disaster risk reduction. Disasters. https://doi.org/10.1111/ j.1467-7717.2009.01126.x

Notoatmojo, S. (2010). Pengembangan Sumber daya manusia. Jurnal LPPM Bidang EkoSosBudKum.

Permana, R. S. (2016). Kesiapsiagaan Masyarakat Terhadap Kerawanan Tanah Longsor Di Das Bompon Kabupaten Magelang [Universitas Gadjah Mada]. http://etd.repository.ugm.ac.id/ penelitian/detail/98618

Peter L. Berger. (1963). Invitation to Sociology: A Humanistic Perspective (1st ed.). Anchor. https://www.amazon.com/ Invitation-Sociology-Perspective-PeterBerger/dp/0385065299

Pramono, M. F., Lahuri, S. Bin, \& Ghozali, M. (2018). Penerapan Manajemen Krisis dalam Pengelolaan Bencana Longsor Banaran, Pulung, Ponorogo. Khadimul Ummah, 1(1). https://doi.org/10.21111/ ku.v1i1.1418

Pramono, R. (2016). Perspektif Sosiologis Dalam Penaggulangan Bencana. Jurnal
Masyarakat Dan Budaya, 18(1), 8196. https://doi.org/http://dx.doi. org/10.14203/jmb.v18i1.342

Rennie, D. L. (1998). Grounded Theory Methodology. Theory \& Psychology. https:// doi.org/10.1177/0959354398081006

Ruslanjari, D. (2010). Peran Kearifan Lokal Dalam Kecepatan Rehabilitas dan Rekonstruksi Bencana Gempa Bumi di Desa Multireligui dan Monoreligi Kasus di Kabupaten Bantul. Jurnal Kebencanan Indonesia, II 93). http://i-lib.ugm.ac.id/ jurnal/detail.php?dataId $=11701$

Saputra, A. (2016). Sosiologi Bencana: Sebuah Refleksi Pasca Gempa dan Tsunami di Aceh. Jurnal Sosiologi USK (Media Pemikiran \& Aplikasi), 9(1), 55-66. https://doi.org/10.24815/jsu

Sarnu, Banaran, P. (2019). Interview.

Saroni, D. (2019). Interview.

Siswanto, Tugurejo, S. (2019). Interview.

Sudarto, Sooko, S. (2019). Interview.

Sukamto, Jurug, S. (2019). Interview.

Thomas E. Drabek. (1986). Human system responses to disaster: An inventory of sociological findings (1st ed.).

Thomas E. Drabek. (2013). The Human Side of Disaster (2nd ed.). CRC Press. https:// www.crcpress.com/The-Human-Side-ofDisaster/Drabek/p/book/9781466506855

Tri Wahyono, T. S. (2019). Interview.

UU No. 24 Tahun 2007 tentang Penanggulangan Bencana, 3 Sekretaris Negara 149 (2007). https://doi. org/10.1174/113564009787531226. 